\title{
Evaluation of Acute Ischemic Stroke Patients Treated with Intravenous Thrombolysis; Experiences of a Stroke Center
}

\section{İntravenöz Trombolitik Tedavi Verilen Akut İskemik İnmeli Hastaların Değerlendirilmesi; Bir İnme Merkezinin Deneyimleri}

\author{
Serhan Yıldırım ๑D, Pınar Bekdik Şirinocak @
}

Kocaeli Derince Traınıng and Research Hospital, Neurology Department,Kocaeli, Türkiye

Cite as: Yıldırım S, Bekdik Şirinocak P. Evaluation of acute ischemic stroke patients treated with intravenous thrombolysis; experiences of a stroke center. Kocaeli Med J 2021;10(2):96-101.

\section{Abstract}

INTRODUCTION: Intravenous thrombolytic (iv-tPA) treatment is a recommended treatment in acute ischemic stroke (AIS). We aimed to evaluate the effectiveness and side effects of this treatment on our patients.

METHODS: We retrospectively evaluated the datas of patients with AIS treated with $0,9 \mathrm{mg} / \mathrm{kg}$ iv-tPA between 2018-2020.

RESULTS: Forty-nine patients were treated with iv-tPA between 2018 and 2020. NIHSS scores at 24th hour were found significantly decreased compared with at onset $(8,3 \pm 4,1$ at onset, $4,9 \pm 5,1$ at 24 th hour, $\mathrm{p}=0,000)$. Thirty-eight $(\% 77,6)$ patients had good clinical outcome. Intracerebral hemorrhage (ICH) was spotted in $3(6,1 \%)$ patients. Systolic blood pressure (ICH group: $163 \pm 59 \mathrm{mmHg}$, non-ICH group: $141 \pm 25 \mathrm{mmHg} p=0,014)$, serum glucose level(ICH group: $173 \pm 117 \mathrm{mg} / \mathrm{dl}$, non-ICH group: $124 \pm 45 \mathrm{mg} /$ $\mathrm{dl}, \mathrm{p}=0,007)$ and mean door-needle time (ICH group: $125 \pm 9$ min., non-ICH group: $137 \pm 54 \mathrm{~min} . \mathrm{p}=0,029)$ were found significantly increased in patients with ICH. Total $4(8,2 \%)$ patients died after iv-tPAtreatment. DISCUSSION AND CONCLUSION: Our study showed that iv-tPA improves the clinical findings of AIS. Additinally high serume glucose level and systolic blood pressure may increase the risk of ICH.

Keywords: ischemic stroke, intravenous thrombolytic, alteplase

\section{Öz}

GIIRIŞ ve AMAÇ: İntravenöz trombolitik (iv-tPA) tedavi, akut iskemik inmeli hastaların tedavisinde önerilen bir yöntemdir. Bu çalışmadaki amacımız iv-tPA'nın hastalarımızdaki etkinliğini ve yan etkilerini incelemektir.

YÖNTEM ve GEREÇLER: Merkezimizde 2018-2020 yılları arasında 0,9mg/kg dozunda iv-tPA alan hastların verileri retrospektif olarak incelendi.

BULGULAR: Merkezimizde 2018-2020 yılları arasında 49 hastanın iv-tPA ile tedavi edildiği saptandı. Iv-tPA ile tedavi edilen hastaların 24. saat NIHSS skorlarının tedavi öncesi NIHSS skorlarına göre belirgin düşük olduğu izlendi(tedavi öncesi $8,3 \pm 4,1 ; 24$. saat $4,9 \pm 5,1, \mathrm{p}=0,000)$. Hastaların 38 'inde $(\% 77,6)$ iyi klinik prognozun olduğu izendi. Üç $(\% 6,1)$ hastada intraserebral kanama olduğu izlendi. İntraserebral kanama olan hastalarda sistolik kan basıncinın(kanama olanlar: $163 \pm 59 \mathrm{mmHg}$, kanama olmayanlar: $141 \pm 25 \mathrm{mmHg} p=0,014)$, serum glukoz düzeyinin(kanama olanlar: $173 \pm 117 \mathrm{mg} / \mathrm{dl}$, kanama olmayanlar: $124 \pm 45 \mathrm{mg} / \mathrm{dl}, \mathrm{p}=0,007)$ ve kapı-iğne sürelerinin(kanama olanlar: $125 \pm 9 \mathrm{dk}$, kanama olmayanlar: $137 \pm 54$ $\mathrm{dk} \mathrm{p}=0,029$ ) daha yüksek olduğu izlendi.

TARTIŞMA ve SONUÇ: Çalışmamız iv-tPA'nın akut iskemik inmeli hastaların klinik bulgularını düzelttiğini gösterdi. Ayrıca yüksek serum glukoz düzeyi ve sistolik kan basıncının da intraserebral kanama riskini artırdığ 1 izlendi.

Anahtar Kelimeler: iskemik inme, intravenöz trombolitik, alteplaz
Geliş tarihi / Received:

13.03.2021

Kabul tarihi / Accepted:

04.08.2021

$$
\begin{array}{r}
\text { Sorumlu Yazar/Corresponding Author: } \\
\text { Serhan Y1ldırı } \\
\text { Kocaeli Derince Traınıng and Research } \\
\text { Hospital, Neurology Department, } \\
\text { Kocaeli, Türkiye } \\
\text { drserhanyildirim @gmail.com } \\
\text { ORCID: 0000-0002-1997-4003 }
\end{array}
$$

P. Bekdik Şirinocak 0000-0002-4644-6572 


\section{INTRODUCTION}

Intravenous thrombolytic (iv-tPA) treatment is a recommended treatment in acute ischemic stroke (AIS). In 1995, National Institute of Neurological Disorders and Stroke study group reported that patients with acute ischemic stroke who were treated with alteplase $0,9 \mathrm{mg} / \mathrm{kg}$ within 3 hours after onset of symptoms had better disability rates(1). ECASS III study showed that iv-tPA had benefit on patients treated 3-4,5 hours after onset of stroke sympthoms(2). In American Hearth Association/American Stroke Association (AHA/ASA) guidelines, iv-TPA was recommended for patients who may be treated in 4,5 hours(3). Usage of iv-tPA in treatment of AIS spreads in our country. In this study, we evaluated the patients with acute ischemic stroke who were treated with iv-tPA

\section{MATHERIAL AND METHODS}

We retrospectively evaluted the datas of patients with AIS in Kocaeli Derince Training and Research Hospital between 20182020. This study was approved by Kocaeli Derince Training and Research Hospital Ethic Committee. Datas were collected from hospital records. Patients or their relatives were phoned for missing datas.

Iv-tPA treatment was applied patients who didn't have any contraindication according to guideline of AHA/ASA (3). IvtPA was given as dose of $0,9 \mathrm{mg} / \mathrm{kg}$ (maximum $90 \mathrm{mg}$ ) over 60 minutes with initial $10 \%$ given as bolus over 1 minute. All patients with acute ischemic stroke who were treated with ivtPA didn't have large vessel occlusion (LVO) (internal carotid artery or M1 segment of middle cerebral artery) in computarized thomography (CT) angiograhy were included to our study. Patients with large vessel occlusions were excluded, because they were treated with endovascular techniques.

Demographic datas, medical history (diseases, drugs,etc), laboratory findings (blood cell counts, glucose, kidney function tests, liver function tests, lipid profile, International Normalized Ratio (INR), hemoglobin A1c, etc), systolic and diastolic blood pressures at admission, sympthom-needle time, sympthom-door time, door-needle time, Alberta Stroke Program Early Computed Tomography Score (ASPECT)(4) on non-contrast brain CT at admission, National Institutes of Health Stroke Scale (NIHSS) score at admission and $24^{\text {th }}$ hour, brain CT findings at $24^{\text {th }}$ hour and modified Rankin score (mRS) at $90^{\text {th }}$ day were collected. Sympthomneedle time was defined as time from onset of sympthoms to bolus injection of iv-tPA. Sympthom-door time was defined as time from onset of sympthoms to arrival to hospital. Door-needle time was defined as time from arrival to hospital to bolus injection of iv-tPA. Intracerebral hematoma ( $\mathrm{ICH})$ types on brain $\mathrm{CT}$ at $24^{\text {th }}$ hour were defined according to European Collaborative Acute Stroke Study (ECASS) classification (5). Subtypes of ischemic stroke were defined according to Trial of Org 10172 in Acute Stroke Treatment (TOAST) classification(6).

Statistical analyzes were made with SPSS 15.0. Categorical variables were expressed as frequencies and percentages.
Continuous variables were expressed as mean (SD) or median (interquartilerange $[\mathrm{IQR}]$ ) for non-normal distribution. Kolmogorov-Smirnov test was used for assessing the normality of distribution. We used Mann-Whitney U, paired T and independent T-tests for continuous data and $\chi^{2}$ for binary and categorical data. All $\mathrm{p}$ values $<0,05$ were considered significant.

\section{RESULTS}

We achieved datas of 49 patients treated with iv-tPA between July 2018 and December 2020.Twenty-eight (57,1\%) patients were male. Mean age of patients was found as $67,4 \pm 12,3$ years (Male:68,5 $\pm 12,5$; female: $66 \pm 12,2 ; \mathrm{p}=0,985$ ). Smoking was found high in males ( $\mathrm{p}=0,04$; OR:0,152, 95\% CI 0,04-0,574). Hypertension (HT) was found increased in females ( $\mathrm{p}=0,014$; OR:11,111, 95\%CI 1,292-95578). Other risk factors were found similar between male and female patients. Sympthom-needle, symptom-door and doorneedle times were found similar between males and females. Mean ASPECT score was found 9,6 $\pm 0,7$ points (Median:10, males: $9,7 \pm 0,6$, females: $9,6 \pm 0,7, p=0,573$ ). In laboratory findings, mean platelet count was increased and mean creatine level was decreased in female patients. Twenty-two (44,9\%) patients had usage of antiaggregants before stroke $(17[34,7 \%]$ patients acetylsalicylic acid (ASA), 2[4,1\%] patients klopidogrel, 3[6,1\%] patients ASA + klopidogrel. Atherosclerotic ischemic stroke was found high in male patients $(\mathrm{p}=0,015)$. Demographic, laboratory and clinical datas were shown in Table 1.

Mean NIHSS score at onset was $8,3 \pm 4,1$ points (Males: 9, $1 \pm 4,6$; females:7, $1 \pm 3,2, p=0,131)$. Mean NIHSS score $24^{\text {th }}$ hour was found as $4,9 \pm 5,1$ points (males: 5,6 $\pm 6,1$, females:3,9 $93,1, \mathrm{p}=0,575$ ). Mean NIHSS score of all patients decreased significantly at $24^{\text {th }}$ hour $(p=0,000, p=0,019$ for males, $p=0,007$ for females). Changes in NIHSS scores were shown in Table 2.

ICH was seen in $3(6,1 \%)$ patients on brain CT performed at $24^{\text {th }}$ hour. One patient had petechial hemorrhage type 2 and 2 patients had parenchimal hematoma type 2 . We found decreased sympthomdoor time (ICH group: 125 \pm 9 min., non-ICH group: 137 $\pm 54 \mathrm{~min}$. $\mathrm{p}=0,029$ ) and increased door-needle time (ICH group: $73 \pm 37 \mathrm{~min}$., non-ICH group: $37 \pm 9$ min. $\mathrm{p}=0,009)$ in patients with $\mathrm{ICH}$. Systolic $\mathrm{BP}$ was found high in patients with $\mathrm{ICH}(\mathrm{ICH}$ group: $163 \pm 59 \mathrm{mmHg}$, non-ICH group: $141 \pm 25 \mathrm{mmHg} \mathrm{p}=0,014)$. In laboratory findings, only serum glucose levels were found increased in $\mathrm{ICH}$ group $(\mathrm{ICH}$ group: $173 \pm 117 \mathrm{mg} / \mathrm{dl}$, non-ICH group: $124 \pm 45 \mathrm{mg} / \mathrm{dl}, \mathrm{p}=0,007$ ).

Good clinical outcomes were seen in $38(77,6 \%)$ of 49 patients. Distribution of mRS was shown in Table 3. Mean ASPECT score was found increased $(p=0,037)$, and NIHSS score at $24^{\text {th }}$ hour was found decreased $(p=0,001)$ in patients with good clinical outcome. In laboratory findings, thyroxine (T4) levels were found high in patients with good clinical outcome $(p=0,029)$. Ischemic stroke in medical history was found high in patients with poor clinical outcome ( $p=0,007$; OR:21,143, 95\%CI 2,046-218,497). Datas of patients with good and bad clinical outcome were shown in Table 4. Four $(8,2 \%)$ patients died. Two $(4,1 \%)$ patients died because of ICH, $1(2 \%)$ patient died because of aspiration pneumonia and 1 patient died because of COVID-19 infection. 
Table 1: Demographic, clinical, radiological and laboratory findings of male and female patients

\begin{tabular}{|c|c|c|c|c|}
\hline & Overall (\%) & Male (\%) & Female $(\%)$ & $\mathbf{p}$ \\
\hline Patients & 49 & $28(57,1)$ & $21(42,9)$ & \\
\hline Age & $67,4 \pm 12,3$ & $68,5 \pm 12,5$ & $66 \pm 12,2$ & 0,985 \\
\hline Hypertension & $37(77,6)$ & $18(64,3)$ & $20(95,2)$ & 0,014 \\
\hline Diabetes Mellitus & $10(20,4)$ & $4(14,3)$ & $6(28,6)$ & 0,291 \\
\hline Smoking & $21(42,9)$ & $17(60,7)$ & $4(19)$ & 0,004 \\
\hline Coronary Artey Disease & $8(16,3)$ & $6(21.4)$ & $2(9,5)$ & 0,438 \\
\hline Hyperlipidemia & $6(12,2)$ & $3(10,7)$ & $3(14,3)$ & 1,000 \\
\hline Stroke History & $5(10,2)$ & $5(17,9)$ & $0(0)$ & 0,062 \\
\hline Atrial Fibrillation & $14(28,6)$ & $7(25)$ & $7(33,3)$ & 0,542 \\
\hline Hearth Failure & $3(6,1)$ & $2(7,1)$ & $1(4,8)$ & 1,000 \\
\hline Sympthom-needle time (min) & $178 \pm 49$ & $181 \pm 46$ & $173 \pm 53$ & 0,316 \\
\hline Sympthom-door time (min) & $135 \pm 51$ & $141 \pm 45$ & $128 \pm 59$ & 0,143 \\
\hline Door-needle time(min) & $39 \pm 14$ & $40 \pm 16$ & $38 \pm 12$ & 0,456 \\
\hline ASPECT & $9,6 \pm 0,7$ & $9,7 \pm 0,6$ & $9,6 \pm 0,7$ & 0,573 \\
\hline NIHSS at onset & $8,2 \pm 4,1$ & $9,1 \pm 4,6$ & $7,1 \pm 3,2$ & 0,131 \\
\hline NIHSS at $24^{\text {th }}$ hour & $4,9 \pm 5,1$ & $5,6 \pm 6,1$ & $3,9 \pm 3,1$ & 0,575 \\
\hline Cardioembolism & $14(28,6)$ & $7(25)$ & $7(33)$ & 0,542 \\
\hline Atherosclerotic & $7(14,3)$ & $7(25)$ & $0(0)$ & 0,015 \\
\hline Lacunary infarction & $10(20,4)$ & $5(17,9)$ & $5(23,8)$ & 0,726 \\
\hline Undefined cause & $18(36,7)$ & $9(32,1)$ & $9(42,9)$ & 0,318 \\
\hline $\mathrm{WBC}\left(/ \mathrm{mm}^{3}\right)$ & $8500 \pm 4109$ & $9085 \pm 5050$ & $7719 \pm 2228$ & 0,234 \\
\hline Neutrophile \% & $62,5 \pm 14,7$ & $61,8 \pm 16,8$ & $63,3 \pm 11,6$ & 0,402 \\
\hline Hemoglobin(gr/dl) & $12,6 \pm 2,3$ & $13,2 \pm 2,5$ & $11,8 \pm 1,8$ & 0,353 \\
\hline $\operatorname{MCV}(\mathrm{fl})$ & $84,7 \pm 13,8$ & $82,6 \pm 17$ & $87,5 \pm 7,1$ & 0,466 \\
\hline Platelet(/mm 3$)$ & $242408 \pm 74653$ & $225642 \pm 56179$ & $264761 \pm 90534$ & 0,029 \\
\hline $\operatorname{MPV}(f l)$ & $8,99 \pm 0,9$ & $9,1 \pm 0,95$ & $8,84 \pm 0,83$ & 0,647 \\
\hline Glucose (mg/dl) & $127 \pm 51$ & $129 \pm 55$ & $123 \pm 47$ & 0,952 \\
\hline Urea $(\mathrm{mg} / \mathrm{dl})$ & $38,2 \pm 18,6$ & $36,3 \pm 11,9$ & $40,8 \pm 25,1$ & 0,505 \\
\hline Creatine(mg/dl) & $0,92 \pm 0,38$ & $0,93 \pm 0,23$ & $0,90 \pm 0,53$ & 0,019 \\
\hline $\operatorname{AST}(\mathrm{U} / \mathrm{L})$ & $39,1 \pm 106,5$ & $27,3 \pm 20,8$ & $54,9 \pm 161,8$ & 0,169 \\
\hline ALT(U/L) & $28,6 \pm 73,2$ & $18,4 \pm 10,3$ & $42,2 \pm 111,2$ & 0,460 \\
\hline GGT(U/L) & $32,4 \pm 40,1$ & $22,6 \pm 10,2$ & $45,3 \pm 58,3$ & 0,123 \\
\hline INR & $1,07 \pm 0,12$ & $1,09 \pm 0,09$ & $1,06 \pm 0,15$ & 0,294 \\
\hline $\mathrm{CRP}(\mathrm{mg} / \mathrm{l})$ & $13,5 \pm 14,9$ & $12,6 \pm 13,6$ & $14,8 \pm 16,7$ & 0,418 \\
\hline Triglyceride(mg/dl) & $133,5 \pm 61,8$ & $126,4 \pm 55,6$ & $143,3 \pm 70$ & 0,409 \\
\hline Total Kolesterol(mg/dl) & $189,1 \pm 42,8$ & $183,6 \pm 43,1$ & $196,8 \pm 42,4$ & 0,904 \\
\hline $\operatorname{HDL}(\mathrm{mg} / \mathrm{dl})$ & $42,3 \pm 13,3$ & $41,2 \pm 14,1$ & $43,7 \pm 12,4$ & 0,827 \\
\hline LDL(mg/dl) & $121,3 \pm 35,9$ & $118,9 \pm 38,8$ & $124,4 \pm 32,1$ & 0,364 \\
\hline $\mathrm{TSH}(\mu \mathrm{U} / \mathrm{ml})$ & $2,78 \pm 6,23$ & $3,11 \pm 7,87$ & $2,26 \pm 1,92$ & 0,250 \\
\hline $\mathrm{T} 3(\mathrm{pg} / \mathrm{ml})$ & $2,57 \pm 0,46$ & $2,62 \pm 0,52$ & $2,5 \pm 0,36$ & 0,184 \\
\hline T4(ng/ml) & $1,22 \pm 0,22$ & $1,18 \pm 0,19$ & $1,27 \pm 0,25$ & 0,234 \\
\hline HbAlc(\%) & $6,25 \pm 1,38$ & $6,5 \pm 1,73$ & $5,91 \pm 0,53$ & 0,256 \\
\hline Systolic BP(mmHg) & $143 \pm 29$ & $147 \pm 27$ & $135 \pm 30$ & 0,387 \\
\hline Diastolic BP(mmHg) & $81 \pm 15$ & $83 \pm 16$ & $77 \pm 14$ & 0,236 \\
\hline Antiaggregant & $22(44,9)$ & $13(46,4)$ & $9(42,9)$ & 0,865 \\
\hline Warfarin & $3(6,1)$ & $2(7,1)$ & $1(4,8)$ & 1,000 \\
\hline $\mathrm{ICH}$ & $3(6,1)$ & $3(10,7)$ & $0(0)$ & 0,250 \\
\hline Good Clinical Outcome & $38(77,6)$ & $20(71,4)$ & $18(85,7)$ & 0,311 \\
\hline Mortality & $4(8,2)$ & $4(14,3)$ & $0(0)$ & 0,125 \\
\hline
\end{tabular}


Table 2: NIHSS Score Changes Between at Onset and at $24^{\text {th }}$ Hours

\begin{tabular}{lccc}
\hline & NIHSS at onset & NIHSS at 24 $4^{\text {th }}$ hour & p \\
\hline Overall & $8,2 \pm 4,1$ & $4,9 \pm 5,1$ & 0,000 \\
Male & $9,1 \pm 4,6$ & $5,6 \pm 6,1$ & 0,019 \\
Female & $7,1 \pm 3,2$ & $3,9 \pm 3,1$ & 0,007 \\
\hline
\end{tabular}

Table 3: Distribution of $\mathrm{mRS}$ at $90^{\text {th }}$ day

\begin{tabular}{cc}
\hline $\mathbf{m R S}$ & $\mathbf{n}(\mathbf{\%})$ \\
\hline 0 & $10(20,4)$ \\
1 & $18(36,7)$ \\
2 & $10(20,4)$ \\
3 & $6(12,2)$ \\
4 & $1(2)$ \\
5 & $0(0)$ \\
6 & $4(8,2)$ \\
\hline
\end{tabular}

\section{DISCUSSION}

In this study, we evaluated the datas of ischemic stroke patients treated with iv-tPA who didn't have LVO. We found that clinical findings of patients significantly recovered in 24 hours after treatment. Additinally $77,6 \%$ of patients had functional independence at $90^{\text {th }}$ day, and $8,2 \%$ of patients died due to ICH or infections. In a study, NINDS reported that $60 \%$ of patients had $\mathrm{mRS} \leq 3$ points(1). In SITS-MOST study, functional independence $(\mathrm{mRS} \leq 2)$ rate of patients was found as $54,8 \%(7)$. In ECASS III study, favourable outcome was seen in $52,4 \%$ of patients treated with iv-TPA in 3-4,5 hours(2). Good clinical outcome was found as $62,7 \%$ in SITS-ISTR study(8).In a recent study, good clinical outcome at $3^{\text {rd }}$ month was seen in $65 \%$ of patients in Turkey $(9)$. Our good clinical outcome rate was found high from other trials. InAHA/ASAguideline published in 2015, endovascular treatment was considered in patients with $\operatorname{LVO}(10)$. In our center, patients with LVO are treated with mechanical thrombectomy. So patients with LVO were excluded from our study. But in these studies were designed before 2015, and patients with LVO were treated with only iv-tPA. But, recanalization rate was found as in $5.9 \%$ patients with distal ICA occlusion after iv-tPA alone in a trial(11). Exclusion of patients with LVO might increase the rate of good clinical outcome in our study.

Early admission of iv-tPAincreases the efficacy of this treatment. Sympthom-door time was found 157 minutes in SITS-ISTR trial(8). Our findings were similar to this trial. But mean symthom-door time was found low in two recent studies performed in $\operatorname{Turkey}(9,12)$. Our hospital is only center treating AIS patients with iv-tPA and endovascular techniques in our region. Most of our patients came from other hospitals. Neurologists in these hospitals don't want to treat AIS patients with iv-tPA due to not having experience it, and they send these patients to our hospital. This situation increased the sympthom-door time of patients. Sympthom-door time may be decreased by spreading the usage of iv-tPA by neurologists in other hospitals or transporting AIS patients to center where patient can be treated. In 2018 AHA/ASA guidelines, it's recommended that patients with stroke findings should be transported to the closest center can administer iv-tPA(3). On the other hand, we have shorter door-needle time from other studies performed in Turkey $(9,12)$. It's recommended that initial bolus dose of iv-tPA should be given to $\geq 50 \%$ of AIS patients within $<60$ minutes after arriving to hospital (door-needle time $<60$ minutes) (3). We found mean door-needle time $<60$ minute. Additionally $94 \%$ of patients had door-needle time $<60$ minutes. We found high door-needle time in patients with poor clinical outcome, but there wasn't significant difference.

Our study showed that NIHSS score at $24^{\text {th }}$ hour was significantly decreased in all patients. We found that NIHSS score at $24^{\text {th }}$ hour decreased significantly in patients with good clinical outcome. Early neurological improvement after iv-tPAis accepted as predictor of recanalization and good clinical outcome(13). We found significant correlation between improvement in NIHSS score at $24^{\text {th }}$ hour and good clinical outcome.

Our study showed that patients with good clinical outcome had high ASPECT scores. ASPECT score $\leq 7$ points is predictor of poor clinical outcome(4). But there isn't any information about association between ASPECT score and clinical outcome in patients treated with iv-tPA in literature. In a recent trial, Das et al reported that lower ASPECT scores were associated with increased risk of $\mathrm{ICH}(14)$.

ICH rate was found as $6,4 \%$ in NINDS trial(1). In SITSMOST trial, ICH was seen in 2,2\% of patients(7). Hacke et al reported that $2,4 \%$ of patients treated with iv-tPA within 3-4,5 hours had ICH in ECASS III trial(2). In a meta-analysis evaluating ATLANTIS, ECASS and NINDS trials, substantial ICH rate was found as 5,9\%(15). Kutluk et al found ICH rate as 4,9\% in a multicenter study performed in Turkey(9). We found similar ICH rates with literature. Patients with ICH had decreased sympthomdoor and increased door-needle times. There isn't any data about association between increased door-needle time and ICH. Cause of increased door-needle time might be prolonged treatment of high SBP levels. As known, iv-tPA is contraindicated in patient with $\mathrm{SBP}>180 \mathrm{mmHg}$ and $\mathrm{DBP}>105 \mathrm{mmHg}(3)$. These patients has resistant $\mathrm{HT}$ and we lost time while decreasing SBP and DBP.

Our study showed that increased SBP and glucose levels were associated with ICH after iv-tPA treatment. In previous studies, high levels of SBP were found as a predictor of $\mathrm{ICH}(16)$. In a recent trial, Nissar et al found increased SBP levels in patients with $\mathrm{ICH}(17)$. But there aren't many studies about association between SBP and ICH after iv-tPA treatment. In same study, serum glucose levels $>185 \mathrm{md} / \mathrm{dl}$ were found as a predictor of ICH. It isn't known well how elevated serum glucose levels increase the risk of ICH. Mishiro et al reported that chronic hyperglycemia aggravated hemorrhagic transformation after ischemia-reperfusion injury by middle cerebral artery occlusion resulting with endotelial injury in diabetic mice(18). This can explain why high glucose levels increase the risk of ICH in AIS.

Our study had some limitations. Our study was designed as retrospectively. Our patient group was small and we didn't have control group. We didn't evaluated blood pressures during and after iv-tPA treatment. 
Table 4: Demographic, Clinical, Radiological and Laboratory Findings of Patients With Good and Poor Clinical Outcome

\begin{tabular}{|c|c|c|c|}
\hline & Good Outcome(\%) & Poor Outcome(\%) & $\mathbf{p}$ \\
\hline $\mathrm{n}(\%)$ & $38(77,6)$ & $11(23,4)$ & \\
\hline Male & $20(52,6)$ & $8(72,7)$ & 0,311 \\
\hline Age & $64,7 \pm 12,2$ & $76,8 \pm 6,9$ & 0,062 \\
\hline Hypertension & $28(73,7)$ & $10(90,9)$ & 0,415 \\
\hline Diabetes Mellitus & $7(18,4)$ & $3(27,3)$ & 0,673 \\
\hline Smoking & $16(42,1)$ & $5(45,5)$ & 1,000 \\
\hline Coronary Artey Disease & $5(13,2)$ & $3(27,3)$ & 0,355 \\
\hline Hyperlipidemia & $3(7,9)$ & $3(27,3)$ & 0,117 \\
\hline Stroke History & $1(2,6)$ & $4(36,4)$ & 0,007 \\
\hline Atrial Fibrillation & $12(31,6)$ & $2(18,2)$ & 0,475 \\
\hline Hearth Failure & $2(5,3)$ & $1(9,1)$ & 0,542 \\
\hline Sympthom-needle time (min) & $173 \pm 49$ & $193 \pm 47$ & 0,808 \\
\hline Sympthom-door time (min) & $133 \pm 54$ & $145 \pm 42$ & 0,354 \\
\hline Door-needle time(min) & $36 \pm 9$ & $48 \pm 23$ & 0,095 \\
\hline ASPECT & $9,76 \pm 0,54$ & $9,18 \pm 0,98$ & 0,037 \\
\hline NIHSS at onset & $7,6 \pm 3,7$ & $10,6 \pm 4,5$ & 0,121 \\
\hline NIHSS at $24^{\text {th }}$ hour & $3,2 \pm 2,2$ & $10,5 \pm 7,8$ & 0,001 \\
\hline Cardioembolism & $12(31,6)$ & $2(18,2)$ & 0,475 \\
\hline Atherosclerosis & $6(15,8)$ & $1(9,1)$ & 0,500 \\
\hline Lacunary infarction & $9(23,7)$ & $1(9,1)$ & 0,419 \\
\hline Undefined cause & $11(28,9)$ & $7(63,6)$ & 0,072 \\
\hline $\mathrm{WBC}\left(/ \mathrm{mm}^{3}\right)$ & $8686 \pm 4569$ & $7854 \pm 1790$ & 0,222 \\
\hline Neutrophile \% & $62,9 \pm 15,7$ & $60,9 \pm 11,3$ & 0,275 \\
\hline Hemoglobin(gr/dl) & $12,6 \pm 2,3$ & $12,7 \pm 2,5$ & 0,853 \\
\hline $\operatorname{MCV}(f l)$ & $84,3 \pm 14,8$ & $86,2 \pm 10,3$ & 0,755 \\
\hline Platelet $\left(/ \mathrm{mm}^{3}\right)$ & $240078 \pm 79435$ & $250454 \pm 57547$ & 0,776 \\
\hline $\operatorname{MPV}(\mathrm{fl})$ & $9,06 \pm 0,89$ & $8,79 \pm 0,96$ & 0,958 \\
\hline Glucose (mg/dl) & $124 \pm 47$ & $135 \pm 64$ & 0,657 \\
\hline Urea (mg/dl) & $37,7 \pm 20,4$ & $40 \pm 10,9$ & 0,134 \\
\hline Creatine(mg/dl) & $0,91 \pm 0,42$ & $0,97 \pm 0,29$ & 0,250 \\
\hline $\operatorname{AST}(\mathrm{U} / \mathrm{L})$ & $43 \pm 120,8$ & $25 \pm 12,9$ & 0,442 \\
\hline $\operatorname{ALT}(\mathrm{U} / \mathrm{L})$ & $30,2 \pm 82,6$ & $23 \pm 20,5$ & 0,981 \\
\hline GGT(U/L) & $30,5 \pm 41,7$ & $39,9 \pm 34,7$ & 0,449 \\
\hline INR & $1,08 \pm 0,13$ & $1,05 \pm 0,12$ & 0,832 \\
\hline $\mathrm{CRP}(\mathrm{mg} / \mathrm{l})$ & $14,9 \pm 16,3$ & $9,81 \pm 8,7$ & 0,346 \\
\hline Triglyceride(mg/dl) & $130,8 \pm 64,3$ & $145,3 \pm 51,5$ & 0,496 \\
\hline Total Kolesterol(mg/dl) & $189,9 \pm 42,6$ & $185,8 \pm 46,7$ & 0,892 \\
\hline $\mathrm{HDL}(\mathrm{mg} / \mathrm{dl})$ & $42,5 \pm 14,5$ & $41,2 \pm 6,2$ & 0,245 \\
\hline $\mathrm{LDL}(\mathrm{mg} / \mathrm{dl})$ & $122,6 \pm 36,1$ & $115,5 \pm 36,9$ & 0,862 \\
\hline $\mathrm{TSH}(\mu \mathrm{U} / \mathrm{ml})$ & $2,78 \pm 6,86$ & $2,79 \pm 2,56$ & 0,188 \\
\hline $\mathrm{T} 3(\mathrm{pg} / \mathrm{ml})$ & $2,61 \pm 0,46$ & $2,41 \pm 0,48$ & 0,748 \\
\hline $\mathrm{T} 4(\mathrm{ng} / \mathrm{ml})$ & $1,25 \pm 0,24$ & $1,13 \pm 0,11$ & 0,029 \\
\hline $\mathrm{HbA1c}(\%)$ & $6,26 \pm 1,45$ & $6,24 \pm 1,10$ & 0,340 \\
\hline Systolic BP(mmHg) & $136 \pm 23$ & $170 \pm 34$ & 0,257 \\
\hline Diastolic BP(mmHg) & $78 \pm 14$ & $90 \pm 18$ & 0,125 \\
\hline Antiaggregant & $17(44,7)$ & $5(45,5)$ & 1,000 \\
\hline Warfarin & $3(7,9)$ & $0(0)$ & 1,000 \\
\hline $\mathrm{ICH}$ & $1(2,6)$ & $2(18,2)$ & 0,122 \\
\hline
\end{tabular}




\section{CONCLUSION}

Iv-tPA is an effective and confident method in treatment of AIS patients without LVO. This treatment reduces the mortality and disability due to AIS. Adminitration by experienced centers may reduce side effects of iv-tPA. Increasing centers which can treat patients with iv-tPA will reduce negative effects of AIS on public. More studies are needed about this topic.

Ethical approval: Kocaeli Derince Training and Research Hospital Clinical Research Ethics Committee (11.03.2021 / 2021/26)

Informed consent: An informed consent form was obtained from all patients.

Funding: None.

Conflict of Interest: None.

\section{REFERENCES}

1. The National Institute of Neurological Disorders and Stroke rt-PA Stroke Study Group. Tissue plasminogen activator for acute ischemic stroke. N Engl J Med 1995;333:1581-7.

2. Hacke W, Kaste M, Bluhmki E, Brozman M, Dávalos A, Guidetti D et al. Thrombolysis with alteplase 3 to 4,5 hours afteracuteischemicstroke.NEnglJMed2008;359(13):131729.

3. Powers WJ, Rabinstein AA, Ackerson T, Adeoye OM, Bambakidis NC, Becker K et al. 2018 Guidelines for the Early Management of Patients With Acute Ischemic Stroke AGuideline for Healthcare Professionals From theAmerican Heart Association/American Stroke Association. Stroke. 2018;49:e46-e99.

4. Pexman JH, Barber PA, Hill MD, Sevick RJ, Demchuk AM, Hudon ME, et al: Use of the Alberta Stroke Program Early CT Score (ASPECTS) for assessing CT scans in patients with acute stroke. AJNR Am J Neuroradiol 2001;22:153442.

5. Tan IY, Demchuk AM, Hopyan J, Zhang L, Gladstone D, Wong $\mathrm{K}$ et al. CT angiography clot burden score and collatera score: correlation with clinical and radiologic outcomes in acute middle cerebral artery infarct. AJNR Am J Neuroradiol 2009;30:525-31.

6. Adams HP, Bendixen BH, Kappelle LJ, Biller J, Love BB, Gordon DL et-al. Classification of subtype of acute ischemic stroke. Definitions for use in a multicenter clinical trial. TOAST. Trial of Org 10172 in Acute Stroke Treatment. Stroke. 1993;24(1): 35-41.

7. Wahlgren N, Ahmed N, Dávalos A, Ford GA, Grond M, Hacke $\mathrm{W}$ et al. Thrombolysis with alteplase for acute ischaemic stroke in the Safe Implementation of Thrombolysis in Stroke-Monitoring Study (SITS-MOST): an observational study. Lancet 2007; 369: 275-82.
8. Ahmed N, Kellert L, Lees KR, Mikulik R, Tatlisumak T, Toni D et al. Results of Intravenous Thrombolysis Within 4.5 to6Hours and Updated Results Within 3 to 4.5 Hours of Onset ofAcute Ischemic StrokeRecorded in the Safe Implementation of Treatment in Stroke International Stroke Thrombolysis Register (SITS-ISTR) An Observational Study. JAMA Neurology 2013;70(7):837-44.

9. Kutluk K, Kaya D, Afsar N, Arsava EM, Ozturk V, Uzuner $\mathrm{N}$ et al. Turkish Thrombolysis Study Group. Analyses of the Turkish National Intravenous Thromboliysis Registry. J Stroke Cerebrovasc Dis 2016;25:1041-7.

10. Powers WJ, Derdeyn CP, Biller J, Coffey CS, Hoh BL, Jauch EC etal. American Hearth Association/American Stroke Association Focused Update of the 2013 Guidelines for the Early Management of Patients With Acute Ischemic Stroke Regarding Endovascular Treatmen. Stroke 2015;46(10):3020-35

11. Saqqur M, Uchino K, Demchuk AM, Molina CA, Garami $\mathrm{Z}$, Calleja $\mathrm{S}$ et al. Site of arterial occlusion identified by transcranial Doppler predicts the response to intravenous thrombolysis for stroke. Stroke 2007;38(3):948-954.

12. Çabalar M, Taşdemir N, Erdoğan HA, Yayla V, Sözer N, Çağırıcı S et al.Akut İskemik İnmede İntravenöz Trombolitik Tedavi Deneyimlerimiz. Bakırkoy Tıp Dergisi 2018;14:71-5 doi: 10.5350/BTDMJB.20161221082709.

13. Kharitonova TV, Melo TP, Andersen G, Egido JA, Castillo J, Wahlgren $\mathrm{N}$ et al. Importance of cerebral artery recanalization in patients with stroke with and without neurological improvement after intravenous thrombolysis. Stroke 2013;44:2513-18. doi: 10.1161/STROKEAHA.111.000048.

14. Das S, Mondal GP, Bhattacharya R, Ghosh KC, Das $\mathrm{S}$, Pattem HK et al.Predictors of Postthrombolysis Outcome and Symptomatic Postthrombolysis Hemorrhage following Intravenous Thrombolysis with Alteplase for Acute Ischemic Stroke. J Neurosci Rural Pract 2020 Apr;11(2):315-324. doi: 10.1055/s-0040-1709946.

15. The ATLANTIS, ECASS, and NINDS rt-PA Study Group Investigators. Association of outcome with early stroke treatment: pooled analysis of ATLANTIS, ECASS, and NINDS rt-PA stroke trials. Lancet 2004; 363: 768-74

16. The NINDS t-PA Stroke Study Group. Intracerebral Hemorrhage After Intravenous t-PA Therapy for Ischemic Stroke. Stroke. 1997;28(11);:2109-18.

17. Nisar T, Hanumanthu R, Khandelwal P. Symptomatic Intracerebral Hemorrhage after Intravenous Thrombolysis: Predictive Factors and Validation of Prediction Models. J Stroke Cerebrovas Dis. 2019;28(11):104360. doi: 10.1016/j. jstrokecerebrovasdis.2019.104360.

18. Mishiro K, Imai T, Sugitani S, et al. Diabetes mellitus aggravates hemorrhagic transformation after ischemicstroke via mitochondrialefects leading to endothelialapoptosis. PLoS One. 2014;9(8):e103818. doi: 10.1371/journal. pone. 0103818 . 